\title{
Effect of chronic exposure to ammonia on alterations of proteins and immunoglobulins in sea bass (Dicentrarchus labrax) serum
}

\author{
Jean-Luc Courdacier*, Gilbert Dutto \\ Ifremer, Route de Maguelone, 34250 Palavas-Les-Flots, France
}

Received November 17, 1998; accepted July 30, 1999

\begin{abstract}
The relationship between serum protein, immunoglobulin concentrations and protein molecular weight profile (PMWP) alterations of sea bass $(131.3 \pm 4.3 \mathrm{~g})$ reared in sea water with sublethal concentrations of ammonia was studied over two periods totalling 116 days. During the exposure period (62 days) the first group (group 1) lived in sea water with $0.204 \mathrm{mg} \cdot \mathrm{L}^{-1}$ unionized ammonia nitrogen equivalent to $12 \%$ of the lethal concentration for $50 \%$ of a population exposed for $96 \mathrm{~h}$ to ammonia $(96-\mathrm{h} \mathrm{LC}$ ) , whilst the second group (group 2) lived in sea water with $0.340 \mathrm{mg} \cdot \mathrm{L}^{-1}$ UIA-N equivalent to $20 \%$ of the $96-\mathrm{h} \mathrm{LC}_{50}$ of ammonia. Then, the two groups were left for a recovery period ( 54 days) in the same water as the control group (group 0 ). The determination of the total immunoglobulin (Ig) concentration was carried out by enzyme-linked immunosorbant assay (ELISA). Gel filtration columns were used for the serum PMWP. Serum Ig concentration of the exposed fish (group 2: $1.76 \pm 0.43 \mathrm{mg} \cdot \mathrm{mL}^{-1}$; group 1: $1.19 \pm 0.33 \mathrm{mg} \cdot \mathrm{mL}^{-1}$ ) was lower than the control group (3.39 \pm $1.01 \mathrm{mg} \cdot \mathrm{mL}^{-1}$ ) after 21 days of exposure period but this difference was reduced at the end of this period (day 62) and treated group Ig concentrations switched to higher than the control group after the recovery period (day 116, group 2: $9.75 \pm 1.84 \mathrm{mg} \cdot \mathrm{mL}^{-1}$; group 1: $7.50 \pm$ $1.22 \mathrm{mg} \cdot \mathrm{mL}^{-1}$ group 0: $6.38 \pm 1.13 \mathrm{mg} \cdot \mathrm{mL}^{-1}$ ). In fact, at the end of the experiment, the cumulative Ig production difference between fish exposed to ammonia and the control was less than $10 \%$. Although a similar evolution of the Ig serum occurred with protein concentration, the serum protein concentration deficit of group 1 was restored at the end of the exposure period (group 2: $46.49 \pm 2.34 \mathrm{mg} \cdot \mathrm{mL}^{-1}$; group 0: $46.74 \pm 1.97 \mathrm{mg} \cdot \mathrm{mL}^{-1}$ ) and the cumulative production during the experiment was not significantly different between group 1 and group 0 . However, this remained lower for group 2. During the exposure period, the PMWP of treated fish moved towards smaller molecular weight proteins. This alteration of the PMWP showed that the $0.2-\mathrm{kDa}$ fraction increased, and another fraction appeared at the end of the exposure period. However, at the end of the recovery period, no difference was found between the PMWPs of control and treated fish. The alterations of the serum protein and Ig of fish reared, for a limited period ( 2 months), in water with sublethal concentrations of ammonia ( $20 \% 96-\mathrm{h} \mathrm{LC}_{50}$ or less) should disappear completely after a few months in normal rearing conditions. () 1999 Ifremer/Cnrs/Inra/Ird/Cemagref/Éditions scientifiques et médicales Elsevier SAS
\end{abstract}

Ammonia / sublethal toxicity / immunoglobulin / proteins / fish culture / Dicentrarchus labrax

Résumé - Modifications des protéines et des immunoglobulines sériques chez le loup (Dicentrarchus labrax) consécutives à une exposition chronique à l'ammoniaque. Les modifications des concentrations en immunoglobulines (Ig) et en protéines ainsi que celles des protéinogrammes sériques ont été suivies pendant 116 jours chez des loups méditerranéens de $(131,3 \pm 4,3 \mathrm{~g})$ élevés en présence de doses sublétales d'ammoniaque. Pendant 62 jours, les poissons ont vécu dans de l'eau de mer additionnée d'ammoniaque à des concentrations de $0,204 \mathrm{mg} \cdot \mathrm{L}^{-1}$ de $\mathrm{NH}_{3}$ correspondant à $12 \%$ de la $96-\mathrm{h} \mathrm{DL}$ so pour le groupe $1 \mathrm{et} 0,340 \mathrm{mg} \cdot \mathrm{L}^{-1}$ de $\mathrm{NH}_{3}$ correspondant à $20 \%$ de la $96-\mathrm{h} \mathrm{DL}_{50}$ pour le groupe 2. Ensuite, l'ensemble des poissons a été élevé pendant 54 jours dans la même eau que celle du groupe témoin (groupe 0 ). L'immunoglobulinémie a été réalisée par dosage immuno-enzymatique (ELISA) ; les différents protéinogrammes sériques ont été effectués en gel filtration sur colonnes. Au cours de la période d'intoxication $\left(21^{\mathrm{e}}\right.$ jour $)$, l'immunoglobulinémie reste inférieure chez les poissons traités (groupe $2: 1,76 \pm 0,43 \mathrm{mg} \cdot \mathrm{mL}^{-1}$; groupe $1: 1,19 \pm 0,33 \mathrm{mg} \cdot \mathrm{mL}^{-1}$ contre $3,39 \pm 1,01 \mathrm{mg} \cdot \mathrm{mL}^{-1}$ pour le groupe 0 ), mais ce déficit diminue à la fin de cette période (jour 62) pour s'inverser lors de la période de récupération (jour $116^{\mathrm{e}}$ : groupe $2: 9.75 \pm 1.84 \mathrm{mg} \cdot \mathrm{mL}^{-1} ; \mathrm{groupe} 1:$ $7.50 \pm 1.22 \mathrm{mg}$; groupe $0: 6.38 \pm 1.13 \mathrm{mg} \cdot \mathrm{mL}^{-1}$ ). De fait, les différences de productions cumulées des Ig entre les groupes traités et les témoins restent inférieures à $10 \%$ en fin d'expérience. La protéinémie suit une évolution similaire à celle des $\mathrm{Ig}$, mais pour le groupe 1 , elle se rétablit dès la fin de la période d'intoxication (groupe $2: 46,49 \pm 2,34 \mathrm{mg} \cdot \mathrm{mL}^{-1}$; groupe $0: 46,74 \pm 1,97 \mathrm{mg} \cdot \mathrm{mL}^{-1}$ ). Sur la durée totale de l'expérience, les productions globales sont équivalentes entre le groupe 1 et le groupe 0 mais restent inférieures pour le groupe 2 . L'étude des protéinogrammes révèle un glissement vers les protéines de faible poids moléculaire et l'émergence d'un nouveau pic en fin de période d'intoxication. Toutes ces modifications disparaissent au cours de la période de récupération. Les modifications protéiques et des Ig, consécutives à une intoxication à l'ammoniaque, de période limitée ( 2 mois) et pour des concentrations égales ou inférieures à $20 \%$ de la $96-\mathrm{h}$ $\mathrm{DL}_{50}$, disparaissent après quelques mois de récupération en conditions standard d'élevage. (C) 1999 Ifremer/Cnrs/Inra/Ird/Cemagref/Éditions scientifiques et médicales Elsevier SAS

Ammoniaque / toxicité sublétale / immunoglobuline / protéine / poisson d'élevage / Dicentrarchus labrax

\footnotetext{
* Corresponding author, e-mail: jean.luc.coeurdacier@ifremer.fr
} 


\section{INTRODUCTION}

Under intensive rearing conditions, and particularly when the water is recycled, the ammonia concentration in the water may increase. The ammonia in the water is the sum of two forms, the unionized fraction $\mathrm{NH}_{3}$ and the ionized fraction $\mathrm{NH}_{4}{ }^{+}$. The relative proportion of the two forms depends on $\mathrm{pH}$, temperature and salinity. The former is much more toxic than the latter but toxicity is probably due to a contribution of both forms [8]. The convention is to express ammonia concentration in terms of total ammonia nitrogen (TA-N) and unionized ammonia nitrogen (UIA-N). The specific biochemical mechanism of ammonia toxicity in fish is not fully explained, but it has been shown that ammonia intoxication impairs ATP production, induces a store depletion of polysaccharide and plasma ions, alters the neuronal synaptic transmission, induces leucopenia, erythropenia, inflammation and degeneration of gills and kidneys [8].

The ammonia 96-h $\mathrm{LC}_{50}$ (lethal concentration for $50 \%$ of a population exposed for $96 \mathrm{~h}$ to ammonia) ranges from $0.32 \mathrm{mg} \cdot \mathrm{L}^{-1}$ UIA-N in rainbow trout (Oncorhynchus mykiss) to $3.1 \mathrm{mg} \cdot \mathrm{L}^{-1}$ UIA-N in channel catfish (Ictalarus punctatus) [8]. The $96-\mathrm{h} \mathrm{LC}_{50}$ for striped bass (Morone saxatilis) is $1.01 \mathrm{mg} \cdot \mathrm{L}^{-1}$ UIA-N and $0.64 \mathrm{mg} \cdot \mathrm{L}^{-1}$ UIA-N for another freshwater dicentrarchid, the hybrid striped bass $(M$. saxatilis $\times M$. chrysops) [11].

Although data in sea water are still scarce, the 96-h $\mathrm{LC}_{50}$ is $1.70 \mathrm{mg} \cdot \mathrm{L}^{-1}$ UIA-N for the sea bass juveniles (Dicentrarchus labrax), $2.55 \mathrm{mg} \cdot \mathrm{L}^{-1}$ UIA-N for the both sea bream (Sparus aurata) and turbot (Psetta maxima) [13] and $0.45 \mathrm{mg} \cdot \mathrm{L}^{-1}$ UIA-N for fingerling coho salmon (Oncorhynchus kisutch) [3].

An ammonia molecule is too small to act as an antigen and cannot directly modify the immune system by acting in the usual way. Moreover, it is a natural endogenous product of fish. However, during acute ammonia poisoning in fingerling coho salmon, high ammonia would be considered to act indirectly on the immune system through its toxic action or as a stressor [10].

The immune response can be modified by several stessors. Both defence mechanisms and non-specific activity may be affected [1]. However, sometimes polluant stressors may enhance certain defence parameters, e.g. an increase in circulating antibodies in the serum of striped bass exposed to water with small amounts of cadmium [15]. More recently, it has been found that antibody concentrations, after vaccination of rainbow trout against Streptococcus iniae, are higher in fish exposed to ammonia; however, there was no correlation with protection [6].

The aim of this study was to examine the correlation between chronic ammonia exposure and alteration in $\mathrm{Ig}$, and total protein concentrations or in the protein molecular weight profile (PMWP), as well as evaluating, by a non-lethal procedure, the capability of sea bass to compensate for these alterations.

\section{MATERIALS AND METHODS}

\subsection{Fish}

For the duration of the experiment, the fish were reared in a soundproofed room with controlled light and environmental parameters. Each tank $\left(1 \mathrm{~m}^{3}\right)$ received a flow of $1 \mathrm{~m}^{3} \cdot \mathrm{h}^{-1}$ of sea water, which was filtered $(20 \mathrm{~mm})$ and UV sterilized and contained the selected ammonia concentration. Temperature was kept at $22 \pm 1{ }^{\circ} \mathrm{C}$, inlet $\mathrm{O}_{2}$ was maintained between 120 and $150 \%$ and outlet over $80 \%$ of saturation [8].

The sea bass were provided by our Ifremer laboratory holding facilities. They were fed on a self-demand system with experimental home-made extruded pellets containing $54.3 \%$ total protein and $15.3 \%$ crude fat on a dry matter basis. Uneaten pellets and faecal particles were collected in a trap [8].

Fish, weighing $131.3 \pm 4.3 \mathrm{~g}$, were acclimated for 41 days and divided into three groups (each in duplicate) of 110 fish. For the next 62 days, one group (group 1) was exposed to $0.204 \mathrm{mg} \cdot \mathrm{L}^{-1}$ UIA-N (12\% of 96-h $\mathrm{LC}_{50}$ ) another group (group 2) was exposed to $0.340 \mathrm{mg} \cdot \mathrm{L}^{-1}$ UIA-N (20\% of $\left.96-\mathrm{h} \mathrm{LC}_{50}\right)$. One group was maintained as a control (group 0). After the exposure period, group 2 and group 1 fish were allowed to recover in sea water without added ammonia for a period of 54 days.

Fifteen fish of each group were bled, by caudal vessel puncture, on days 0,21 and 62 of the exposure period and at the end of the recovery period (day 116). The blood was allowed to clot at room temperature and the serum was extracted by centrifugation (15 $000 \mathrm{~g} ; 5 \mathrm{~min}$ ) and stored at $-20^{\circ} \mathrm{C}$ until needed.

\subsection{Total serum protein concentration}

The total serum protein content was determined by an autoanalyser (Cobas Mira Roche) with the proteinkit (BioMérieux, Marcy-l'Etoile, France) based on the principle of the biuret reaction. Bovine serum albumin was used as standard and the data were expressed in $\mathrm{mg} \cdot \mathrm{mL}^{-1}$.

\subsection{Protein molecular weight profile}

Pools of sera from ten fish were initially screened by gel filtration on a ultraspherogel column Beckman Sec4000 with pre-column usg Sec Guard. Then, the serum pools of interest were filtered by cellulose triacetate filter (Whatman 20KDA MWCO according to the manufacturer's recommendations), and the fraction lower than $20 \mathrm{kDa}$ chomatographed on a Beckman Sec2000 with pre-column usg Sec Guard. The separation of the serum fractions by gel filtration was carried out according to the technique developed by Romestand et al. [16] with some modification. Briefly, the column was equilibrated with $\mathrm{NaH}_{2} \mathrm{PO}_{4}$. $\mathrm{Na}_{2} \mathrm{SO}_{4} 100 \mathrm{mM}$ at $\mathrm{pH} 7.4$ and eluted with the same buffer. All fractions were measured at $280 \mathrm{~nm}$ with an absorbance detector ISCO UA-6; protein molecular 
Table I. Serum protein and immunoglobulin concentrations.

\begin{tabular}{lccccccc}
\hline & & & & \multicolumn{2}{c}{ Protein $\left(\mathrm{mg} \cdot \mathrm{mL}^{-1}\right)$} & \multicolumn{2}{c}{ Immunoglobulin $\left(\mathrm{mg} \cdot \mathrm{mL}^{-1}\right)$} \\
\cline { 5 - 8 } Period & Day & Group & Size of sample & Mean & $95 \%$ confidence & Mean & $95 \%$ confidence \\
\hline Exposure period & 0 & origin & 30 & 28.39 & 1.61 & 1.31 & 0.43 \\
& 21 & 0 & 29 & 40.74 & 1.70 & 3.39 & 1.01 \\
& 21 & 1 & 30 & 37.24 & 1.84 & 1.19 & 0.33 \\
& 21 & 2 & 28 & 36.11 & 2.74 & 1.76 & 0.43 \\
& 62 & 0 & 30 & 46.74 & 1.97 & 7.32 & 2.02 \\
Recovery period & 62 & 1 & 29 & 46.49 & 2.34 & 5.9 & 1.55 \\
& 62 & 2 & 29 & 42.74 & 1.89 & 4.06 & 1.01 \\
& 116 & 0 & 30 & 43.58 & 2.17 & 6.38 & 1.13 \\
& 116 & 1 & 29 & 46.56 & 2.40 & 7.50 & 1.22 \\
\end{tabular}

weight profiles were processed with SigmaPlot 3.0 software. The fractions were collected with a fraction collector ISCO SIGNET and stored at $-20^{\circ} \mathrm{C}$ to detect Ig fragment.

\subsection{Serum immunoglobulin concentration}

Serum Ig was quantified by a double monoclonal antibody sandwich enzyme-linked immunosorbent assay (ELISA) $[2,4,5]$. This technique was slightly modified; briefly, serum Ig was quantified by sandwich-ELISA using a pool of normal sea bass sera as standard [12]. Two monoclonal (for whole Ig molecule) and two polyclonal (for Ig fragments) antibodies against sea bass Ig were used, the first antibody crude, as a coating, and the second one biotinilated, as a tracer. Residual binding sites were blocked with $5 \%$ skimmed milk in phosphate-buffered saline (PBS) and the plates were washed with $0.05 \%$ Tween 20 in PBS. Streptavidin-labelled with horseradish peroxidase and ortho-phenylenediamine dihydrochloride permitted the revelation. The absorbance was measured at $492 \mathrm{~nm}$ using a labsystem multiscan RC monitored by GENESIS 1.79 software (labsystems). The data were expressed in $\mathrm{mg} \cdot \mathrm{mL}^{-1}$.

\subsection{Statistics}

Statistics (arithmetic mean, confidence interval, ANOVA, etc.) were carried out with SigmaStat 2.0 software (Jandel Scientific).

Except if there were more details, results were expressed as arithmetic means $(95 \%$ confidence interval and for comparing groups $P<0.05$.

\section{RESULTS}

\subsection{Duplicate}

Each group was followed in duplicate and nonstatistical differences were found between duplicates for protein or Ig concentrations $(0.94<P<0.09$ with 28 degrees of freedom). Consequently, data from the duplicate groups were pooled and treated as one group for further analysis.

\subsection{Total protein}

\subsubsection{Serum concentration (table I)}

On day 21 of the exposure period the protein concentrations (figure 1, lines) of the treated groups were significantly lower than the control group concentration (group 0: $40.74 \pm 1.70 \mathrm{mg} \cdot \mathrm{mL}^{-1}$; group 1: $37.24 \pm 1.84 \mathrm{mg} \cdot \mathrm{mL}^{-1}$ and group 2: $36.11 \pm$ $2.74 \mathrm{mg} \cdot \mathrm{mL}^{-1}$ ). From days 21 to 62 , the protein concentration increase was equal between groups 2 and 0 . The increase for group 1 was higher than that for group 0 , compensating for the protein concentration deficit of the first 21 days. During the recovery period, the protein concentration did not change significantly for group 1 and group 0 . However, the group 2 protein concentration continued to increase and became higher than for the other two groups $(43.58 \pm$ $2.17 \mathrm{mg} \cdot \mathrm{mL}^{-1}, 46.56 \pm 2.40 \mathrm{mg} \cdot \mathrm{mL}^{-1}$ and $50.96 \pm$ $3.03 \mathrm{mg} \cdot \mathrm{mL}^{-1}$, respectively).

The total protein production including conservation and increase can be calculated from the surface under the curves and is expressed as $\mathbf{m g} \cdot \mathrm{mL}^{-1} \cdot$ day $^{-1}$ (figure 1, vertical bars). The cumulated production during the exposure period is lower for the treated groups, with a significant statistical difference only at the end of this period $(P=0.006)$. This tendency was inverted during the recovery period and cumulative production throughout the experiment was not different between group 1 and group 0 but remained lower for group 2 .

\subsubsection{Protein molecular weight profile}

The curve obtained from the pooled sera by chromatography on Sec4000 presented five or six peaks, classed by their retention volume and expressed as $\mathrm{mL}$ (A: $6.0 ; \mathrm{B}: 8.0 ; \mathrm{C}: 9.8 ; \mathrm{D}: 11.9 ; \mathrm{E}: 12.5$ and F: 13.6). The bar chart (figure 2) is the expression of the percentage of each fraction. The alterations started on day 21 for group 2 with an increase in fraction $D$ and the emergence of fraction $E$, and became more marked at the end of the exposure period (day 62) for group 2 


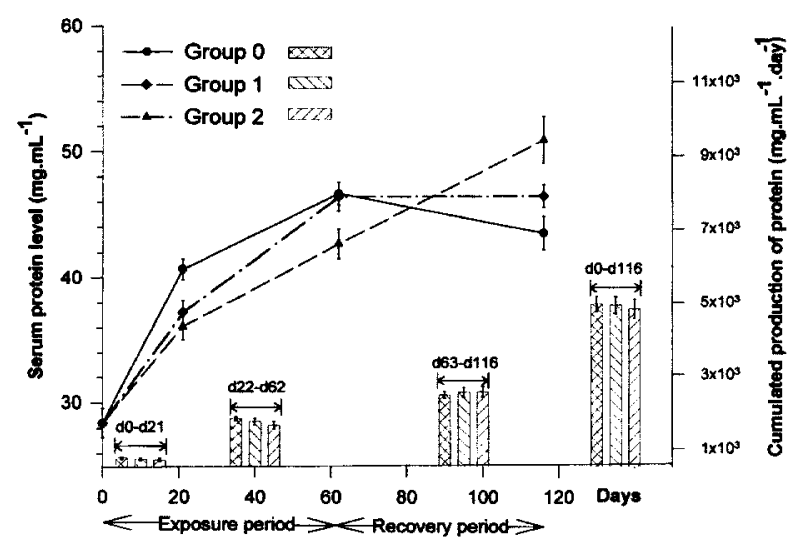

Figure 1. Kinetics of total proteins in serum (lines). The fish were reared in sea water with $0.204 \mathrm{mg} \cdot \mathrm{L}^{-1}$ UIA-N (group 1) and $0.340 \mathrm{mg} \cdot \mathrm{L}^{-1}$ unionized ammonia nitrogen unionized ammonia nitrogen (UIA-N) (group 2) during the exposure period (days 0-62) and in the same water as the control group (group 0) during the recovery period (days 63-116). Means are expressed in $\mathrm{mg} \cdot \mathrm{mL}^{-1} \pm 95 \%$ confidence interval. The cumulated production of total protein (vertical bars) including conservation and increase is represented by the surface under the curve chart and is expressed as $\mathrm{mg} \cdot \mathrm{mL}^{-1} \cdot \mathrm{day}^{-1} \pm$ $95 \%$ confidence interval.

and group 1. However, this alteration disappeared after the recovery period.

If the proteins are divided into two groups (the molecular weight of fraction $D$ is approximately $20 \mathrm{kDa}$, it is between ribonuclease, $13.7 \mathrm{kDa}$, and carbonic anhydrase, $29 \mathrm{kDa}$ ) of high molecular weight (MW): A, B, C, and low MW: D, E, F, a transition of the distribution to low MW protein is shown. The ratio $\mathrm{DEF} / \mathrm{ABC}$ (figure 3) increased with the level and duration of treatment. This alteration disappeared after the recovery period.

The curve obtained by chromatography on Sec2000 of the fraction less than $20 \mathrm{kDa}$ of pooled sera (fig-

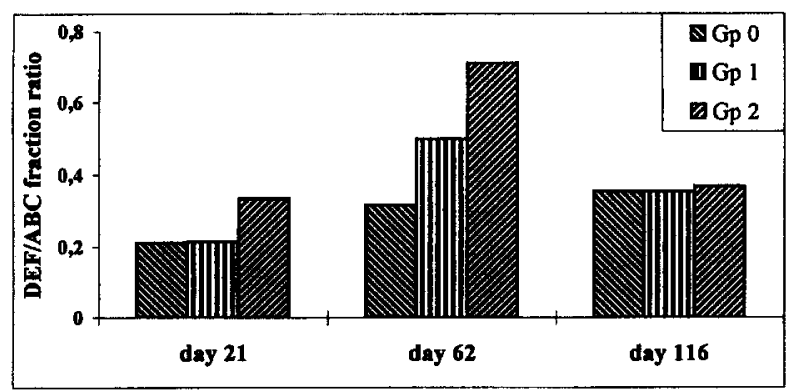

Figure 3. Alteration of the molecular weight protein distribution. The proteins are divided into two groups: peaks A, B, C, and peaks D, E, F (D corresponds roughly to $20 \mathrm{kDa}$ ) The bars represent the ratio $\mathrm{DEF} / \mathrm{ABC}$.

ure 4) presented curves with three or four peaks, classed by their retention volume and expressed as $\mathrm{mL}$ (p1: 11.8; p2: 12.8; 3 : 13.4; 4 : 14.2). On day 21 , the shapes of the curves of the different groups were similar with three fractions (p1; p2; p4), including group 2 , on day 21 . (The $\mathrm{p} 2$ fraction has the same retention volume as uracil: $112 \mathrm{Da}$. Extrapolation for the other fractions would not be correct, since molecules lower than $1 \mathrm{kDa}$ are out of the range of Sec2000.) On day 62, the group 1 and 2 graphs showed a fourth fraction (p3: arrow) just before the lowest. The $\mathrm{p} 3$ fraction disappeared after the recovery period.

\subsection{Immunoglobulins}

\subsubsection{Serum concentration (table I)}

The Ig concentration (figure 5 , lines) in the treated groups did not change significantly until day 21 of the exposure period; however, Ig concentration in the control group increased in this period (group 0: $3.39 \pm$ 1.01; group 1: $1.19 \pm 0.33$; group 2: $1.76 \pm 0.21$ )

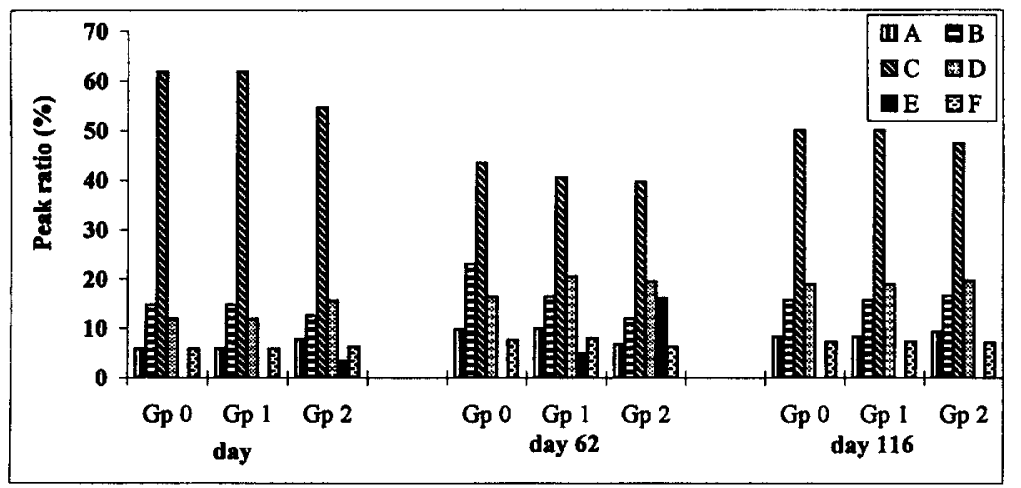

Figure 2. Protein molecular weight profiles of pools of sera from ten fish were separated by gel filtration on an ultraspherogel column Beckman Sec4000 with pre-column usg Sec Guard with $\mathrm{NaH}_{2} \mathrm{PO}_{4} . \mathrm{Na}_{2} \mathrm{SO}_{4} 100 \mathrm{mM}$ at $\mathrm{pH} 7.4$ as buffer. The bars represent the percentage of each fraction calculated as the ratio of surfaces. The arrows show the emergence of a new fraction (peak $\mathrm{E}$ ). 


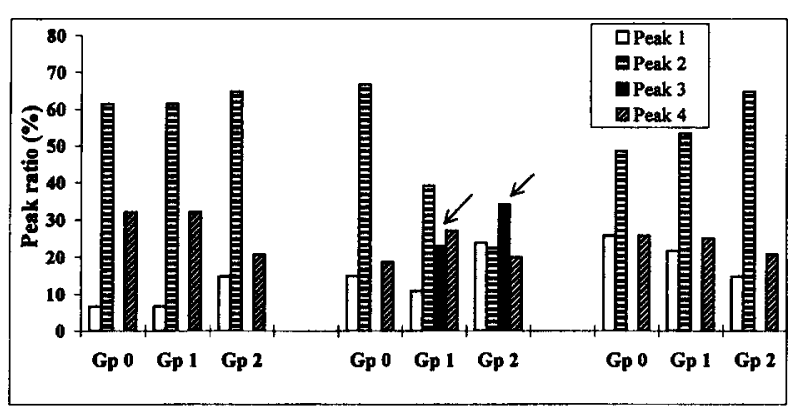

Figure 4. Protein molecular weight profiles of serum fractions with a molecular weight lower than $20 \mathrm{kDa}$. Pools of sera from ten fish were filtered with cellulose triacetate filter (Whatman 20KDA MWCO) and separated by gel filtration on a column Beckman Sec2000 with pre-column usg Sec Guard with $\mathrm{NaH}_{2} \mathrm{PO}_{4} \cdot \mathrm{Na}_{2} \mathrm{SO}_{4} 100 \mathrm{mM}$ at pH 7.4 as buffer. The bars represent the percentage of each fraction calculated as the ratio of surfaces. Fraction 2 has the same retention volume as Uracil (112 Da).

From day 21 to day 62 group $1 \mathrm{Ig}$ concentration increased as that of group 0 , whilst that of group 2 was lower than group 0 . At the end of the exposure period, treated groups were still statistically lower than group 0 , even if group 1 and group 0 only differed with $P=$ 0.06 . During the recovery period, $\mathrm{Ig}$ concentration increased in the treated groups (group 1 from $5.9 \pm$ 1.55 to $7.50 \pm 1.22$ and group 2 from $4.06 \pm 1.01$ to $9.75 \pm 1.84)$. At the end of recovery period, Ig concentration of group 0 became the lowest.

The cumulative production of Ig (calculated as defined for proteins; figure 5, bars) of treated groups,

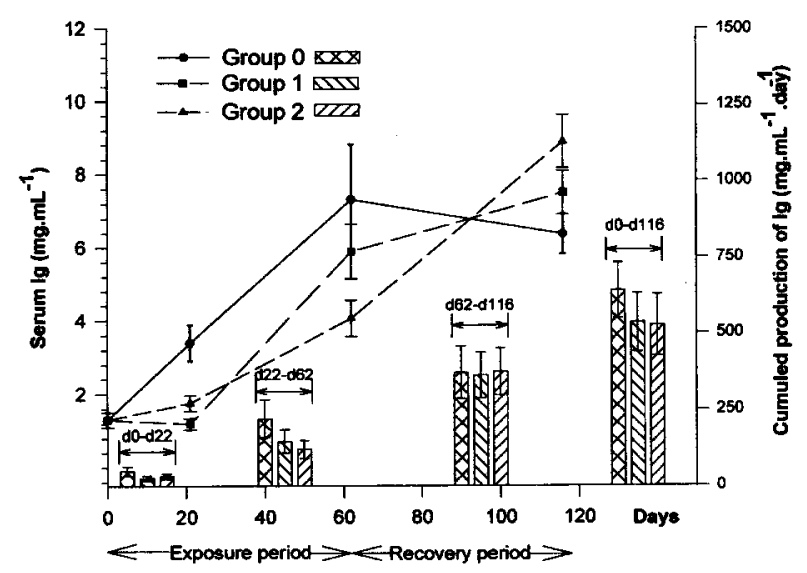

Figure 5. Kinetics of immunoglobulin in serum (line). The fish were reared in sea water with $0.204 \mathrm{mg} \cdot \mathrm{L}^{-1}$ UIA-N (group 1) and $0.340 \mathrm{mg} \cdot \mathrm{L}^{-1}$ UIA-N (group 2) during the exposure period (days $0-62$ ) and in the same water as the control group (group 0) during the recovery period (days 63-116). Means are expressed in $\mathrm{mg} \cdot \mathrm{mL}^{-1} \pm$ $95 \%$ confidence interval. The cumulated production immunoglobulin (vertical bars) including conservation and increase is represented by the surface under the curve chart and is expressed as $\mathrm{mg} \cdot \mathrm{mL}^{-1} \cdot$ day $^{-1}$ $\pm 95 \%$ confidence interval. during the exposure period, was lower than group 0 with a significant statistic difference on day $21(P=$ $0.01)$ but only group 2 still differed $(P=0.01)$ at the end of this period. During the recovery period the cumulative productions were similar in the three groups. Cumulative Ig productions, throughout the experiment, were lower in the treated groups than in the control.

\subsubsection{Immunoglobulin in chromatographied fractions}

The occurrence of Ig fragments was researched in $\mathrm{D}, \mathrm{F}$ and $\mathrm{p} 3$ fractions, with double polyclonal antibody ELISA. No Ig fragment was found.

\section{DISCUSSION}

First of all, a variation in protein and Ig concentrations versus time of the control group was observed. Protein concentration alterations over the year have been recorded in sea bass broodstock [5]. A regular increase has also been observed in protein and $\mathrm{Ig}$ serum concentrations in sea bass fry from 40 up to $200 \mathrm{~g}$ in weight, with fluctuation before stabilization around $350 \mathrm{~g}$ in weight.

Actually, most agents investigated as stress have other detrimental actions (infection, toxicity, etc.) [1]. Ammonia can be considered as toxic [14] or as a stressor [10] or both [6].

The diminution of serum protein concentration and the relative increase in low molecular weight proteins may be due to an augmentation of catabolism, a possible utilization of these compounds for metabolic purposes or the necrosis of cells and consequent impairment in protein synthetic machinery [9]. In this study, during the exposure period, the lower increase in protein concentrations and the protein molecular weight profile alterations, with a general transition to protein MW lower than $20 \mathrm{kDa}$, started earlier in group 2 (day 21) and became obvious in the treated groups at the end of this period (day 62). These alterations seem to be in relation to dose and time (figure 3 ), which assume a dose dependence and probably a toxic action. On day 62 , the fish of group 2 started to compensate and had the same production of protein as those of group 0 and, moreover, those of group 1 started to compensate for the protein level deficit. This compensation suggested a stress action as defined by Selye and reported by Wedmeyer [20]: "The various physiological changes that occur as fish respond to stressful challenge are adaptive in nature and are required to achieve acclimation" and data found by Ingram [7] showed a similar movement in protein molecular weight profiles of brown trout injected with PBS, which also suggested a stress action. Actually, ammonia may act as a toxin and a stressor.

The increase in free amino acid content in fish tissues, under ambient ammonia, has been explained by protein degradation and a lower use of free amino acids [9] and by a rapid turn over of proteins [17]. This 
can be compared with the increase in low molecular weight proteins, and an alternative hypothesis can also be proposed: some of these low molecules were kept as a reserve to be used later to build bigger proteins. The higher production after intoxication in treated groups, and the equal cumulated production over all three groups, suggest that the fish had to restock this reserve unbalanced by poisoning. Another explanation of the higher production in treated groups, during the recovery period, could be a boosting resulting from a feedback action.

Information about the action of ammonia on fish Ig is very scarce but vaccination of rainbow trout against Streptococcus iniae [6] or against Aeromonas hydrophila [19] induced an augmentation of antibodies. However, several works studying pollution action on fish immune system reported an augmentation [15] or a reduction [1] of antibody titre after stress induced by heavy metals, although sewage did not change the specific antibodies or total immunoglobulins of dab (Limanda limanda) [18]. In this present work, the Ig concentration did not increase at the beginning (day 21) of the exposure period. Then adaptation appeared with higher Ig production but the difference on day 62 , between group 0 and group 1 , was still important (even if $P=0.06$ ) and greater between group 0 and group 2 than at the beginning of the exposure period. This evolution resembled that of the proteins but it also presented a time lag for daily and cumulative production. However, Ig or Ig fragments could not be detected in low chromatography fractions which denies an augmentation of lysis and strengthens the idea of a reserve, which is consistent with the higher production in treated groups during the recovery period. Although ammonia also affects Ig concentration, it is not conclusive whether it acts directly or through a general protein alteration.

Increase in protein and Ig productions after ammonia exposure assumes a boosting by ammonia and it is consistent with findings by Sommer [19] and Hurvitz [6]. However, the latter proved the lack of correlation between antibody level and protection. In this case [6], a higher Ig production, as a boosting, would highlight a detrimental action of ammonia. The loss of efficiency of those antibodies would be compensated by a higher production.

It can be concluded that alteration of serum protein and Ig concentrations, in fish reared in water with sublethal ammonia concentrations, for a period of 2 months should completely disappear after a few months in normal rearing conditions. However, it is not known whether the fish would adapt to a sublethal ammonia concentration in water when exposed for longer periods during their lifetime.

\section{Acknowledgement}

We are grateful to Dr Stuart Hetherington of Mannin Seafarm, Isle of Man for critical reading of the manuscript.

\section{REFERENCES}

[1] Anderson D.P., Immunological indicators of environmental stress on immune protection and disease outbreaks, Am. Fish. Soc. Symp. 8 (1990) 38-50.

[2] Bourmaud C.A.F., Romestand B., Bouix G., Isolation and partial characterization of IgM-like seabass ( $D i$ centrarchus labrax L., 1758) immunoglobulins, Aquaculture 132 (1995) 53-58.

[3] Buckle J.A., Acute toxicity of unionised ammonia to fingerling coho salmon, Progress Fish Cult. 40 (1978) 30-32.

[4] Breuil G., Vassiloglou B., Pepin J.P., Romestand B., Ontogeny of IgM-bearing cells and changes in the immunoglobulin $\mathrm{M}$-like protein level (IgM) during larval stages in sea bass (Dicentrarchus labrax), Fish Shellfish Immunol. 7 (1997) 29-43.

[5] Coeurdacier J.L., Pepin J.F., Fauvel C., Legall P., Bourmaud A.F., Romestand B., Alterations in total protein IgM and specific antibody activity of male and female sea bass (Dicentrarchus labrax L., 1758) serum following injection with killed Vibrio anguillarum, Fish Shellfish Immunol. 7 (1997) 151-160.
[6] Hurvitz A., Bercovier H., Van Pijn J., Effect of ammonia on the survival and the immune response of rainbow trout (Oncorhynchus mikiss Walbaum) vaccined against Streptococcus iniae, Fish Shellfish Immunol. 7 (1997) 45-53.

[7] Ingram G.A., Alexander J.B., Serum protein changes in brown trout (Salmo trutta L.) after single injections of soluble and cellular antigens, J. Fish Biol. 11 (1977) 283-291.

[8] Lemarié G., Covès D., Dutto G., Gasset E., Person-Le Ruyet J., Chronic toxicity of ammonia for European sea bass (Dicentrarchus labrax) juveniles, in: Swanson C., Young P. (Eds.), MacKinley Int. Congr. on the biology of fish, American Fisheries Society, Bethesda, 1996, pp. 65-76.

[9] Malla Reddy P., Bashamohideen M., Alteration in protein metabolism in selected tissues of fish, Cyprinus carpio, during sublethal concentration of cypermethrin, Environ. Monit. Assess. 36 (1995) 183-190.

[10] Möck A., Peters G., Lysozyme activity in rainbow trout, Oncorhynchus mikiss (Walbaum), stressed by

Aquat. Living Resour. 12 (4) (1999) 
handling, transport and water pollution, J. Fish Biol. 37 (1990) 873-885.

[11] Oppenborn J.B., Goudie C.A., Acute and sublethal effects of ammonia on striped bass and hybrid striped bass, J. World Aquac. Soc. 24 (1993) 90-101.

[12] Pepin J.F., Le Gall P., Fauvel C., Etude de la cinétique des immunoglobulines et des anticorps de l'ovocyte jusqu'à la larve chez le loup (Dicentrarchus labrax), Ichtyophylosiol. Acta 20 (1997) 87-101.

[13] Person-Le Ruyet J., Chartois H., Quemener L., Comparative acute ammonia toxicity in marine fish and plasma ammonia response, Aquaculture 136 (1995) 181-194.

[14] Randall Robinette H., Effect of selected sublethal of ammonia level on the growth of channel catfish (Ictalurus punctatus), Progress Fish Cult. 38 (1976) 26-29.

[15] Robohm R.A., Paradoxical effects of cadmium exposure an antibacterial antibody responses in two fish species: inhibition in cunners (Tautogolabrus adspersus) and enhancement in striped bass (Morone saxatilis), Vet. Immunol. Immunopathol. 12 (1986) 251-262.
[16] Romestand B., Breuil G., Bourmaud C.A.F., Coeurdacier J.L., Bouix G., Development and characterisation of monoclonal antibodies against sea bass immunoglobulins Dicentrarchus labrax Linnaeus, 1758, Fish Shellfish Immunol. 5 (1995) 347-357.

[17] Sashikala R., Mohan P.K., Indira K., Protein degradation and transamination patterns in a fresh water fish under ambient ammonia stress, Environ. Ecol. 3 (1985) 496-499.

[18] Secombes C.J., Fletcher T.C., White A., Costello M.J., Stagg R., Houlihan D.F., Effects of sewage sludge on immune responses in the dab (Limanda limanda L.), Aquat. Toxicol. 23 (1992) 217-230.

[19] Sommer C.V., Binkowski F.P., Schalk M., Bartos J.M., Stress factors that can affect studies on drug metabolism in fish, Vet. Hum. Toxicol. 28 (Suppl. 1) (1986) $45-54$.

[20] Wedmeyer G.A., Barton B.A., McLeay D.J., Stress and acclimation, in: Schreck C.D., Moyle P.B. (Eds.), Methods for Fish Biology, American Fisheries Society, Bethesda, MA, 1990, 451-48. 